\title{
Peran Pemerintah Desa Dalam Pembangunan
}

\section{(Studi kasus di Desa Laba Besar, Kecamatan Loloda Selatan)}

\author{
Yuliana Ngongano \\ Deiby Ch. Tinggogoy \\ Program Studi Ilmu Administrasi Negara Fishum-universitas Halmahera-Tobelo
}

\begin{abstract}
ABSTRAK
Penelitian ini secara umum bertujuan mengetahui gambaran nyata mengenai bagaimana peran pemerintah desa dalam pembangunan. Peran menjadi indicator awal berhasil tidaknya seorang kepala desa dan perangkat desa dalam melaksanakan tugas-tugasnya. Dalam penelitian ini peneliti menggunakan Teknik observasi, wawancara, dan dokumentasi. Berdasarkan hasil penelitian mengenai peran pemerintah desa dalam pembangunan dapat disimpulkan bahwa masyarakat mempunyai peran yang kurang baik karena apparat desa kurang mengoptimalkan peran tersebut. macetnya suatu pembangunan desa disebabkan pemerintah desa belum dapat meningkatkan taraf hidup masyarakat. Hal ini dipengaruhi oleh adanya kurangnya koordinasi antara pemerintah dengan perangkat desa lainnya, kurangnya ketegasan dalam menjalankan fungsinya sebagai pemerintah desa atau kepala desa.
\end{abstract}

Kata kunci: Pembangunan, Pemerintah Desa

\section{PENDAHULUAN}

Pemerintah desa mempunyai peranan yang sangat berpengaruh terutama dalam upaya untuk menciptakan iklim yang mendorong tumbuhnya prakarsa dan swadaya masyarakat di pedesaan, yang dilakukan melalui pesan-pesan pembangunan, pengarahan kepada masyarakat untuk berpartisipasi dalam pembangunan dan penyaluran aspirasi masyarakat. Partisipasi masyarakat desa diwujudkan dalam bentuk pengarahan dan pemanfaatan daya dan dana yang ada dalam masyarakat untuk meningkatkan kegiatan pembangunan di daerah pedesaan sehingga keberhasilan pembangunan dalam masyarakat tidak selalu ditentukan oleh tersedianya sumber dana keuangan dan manajemen keuangan tetapi lebih banyak dipengaruhi oleh peran serta dan respons masyarakat terhadap pembangunan atau dapat disebut sebagai partisipasi masyarakat. Pencapaian keberhasilan partisipasi masyarakat dalam pembangunan diperlukan kepemimpinan lokal yang cakap, berwibawa dan diterima oleh masyarakat.

Keadaan yang terlihat di Desa Laba Besar Kecamatan Loloda selatan, yaitu dimana pemerintah desa, dalam hal ini kepala desa dalam membuat program untuk pembangunan desa tidak melibatkan masyarakat untuk bersama-sama menyusun dan mempertimbangkan program pembangunan yang sesuai dengan apa yang menjadi kebutuhan masyarakat setempat sehingga menimbulkan kekecewaan.

Pada kenyataannya masyarakat setempat sangat berharap agar pemerintah desa dapat menjalankan tugasnya secara efektif dan efisien, namun pada kenyataannya yang terjadi tidak sesuai dengan apa yang menjadi harapan. Dengan demikian, pemerintah desa sebagai pelaksana aturan-aturan 
yang ada dalam ruang lingkup desa, dapat dikatakan masih kurang optimal dalam menjalankan tugasnya sepenuhnya.

Untuk mencapai tujuan negara sebagaimana dimaksud didalam pembukaan Undang-undang Dasar 1945, maka pemerintah bersama seluruh rakyat Indonesia harus bisa melaksanakan pembangunan nasional di segala bidang, mulai dari tingkat pusat sampai ke tingkat pedesaan. Pembangunan itu sendiri dapat diartikan sebagai suatu proses perbaikan yang berkesinambungan atas suatu masyarakat atau suatu sistem sosial secara keseluruhan menuju kehidupan yang lebih baik atau lebih manusiawi (Todaro, 2000: 21). Lebih lanjut, Todaro menjelaskan bahwa hakikat pembangunan harus mencerminkan perubahan total suatu masyarakat atau penyesuaian suatu sistem sosial secara keseluruhan, tanpa mengabaikan keragaman kebutuhan dasar dan keinginan individual maupun kelompok-kelompok sosial yang ada didalamnya, untuk bergerak maju maupun suatu kondisi kehidupan yang serba lebih baik, secara material maupun spiritual.

Dengan demikian, pembangunan sangat penting untuk dilakukan baik secara sentralisasi maupun desentralisasi sehingga pembangunan tidak hanya penting dilakukan di pusat tetapi juga harus sampai di pedesaan. Rohardjo Adjasasmita (2006: 3), menjelaskan bahwa pembangunan pedesaan merupakan bagian integral dari pembangunan nasional, sebagai usaha peningkatan kualitas sumber daya manusia pedesaan dan masyarakat secara berkelanjutan berdasarkan pada prestasi dan kemampuan pedesaan. Hal ini memperlihatkan bahwa dalam pelaksanaannya pembangunan pedesaan sudah seharusnya mengacu pada pencapaian tujuan pembangunan yaitu mewujudkan kehidupan masyarakat pedesaan yang mandiri, maju, sejahtera, dan berkeadilan.

Dengan demikian, agar pembangunan di desa dapat berjalan sesuai dengan harapan bersama maka pemerintah desah harus dapat menjalankan tugasnya dengan baik dan juga harus didukung oleh peran serta masyarakat yaitu dengan berpartisipasi melaksanakan pembangunan.

\section{TINJAUAN PUSTAKA}

\section{Desa}

Pengertian desa dijelaskan dalam Peraturan Pemerintah Nomor 72 Tahun 2005 adalah kesatuan masyarakat hukum yang memiliki batas-batas wilayah yang berwenang untuk mengatur dan mengurus kepentingan masyarakat setempat berdasarkan asal-usul dan adat istiadat setempat diakui dan dihormati dalam sistem Pemerintah Kesatuan Negara Kesatuan Republik Indonesia.

Pemerintah desa dipimpin oleh Kepala Desa dan dibantu kaur pemerintahan, yang sesuai dengan bidang masing-masing yang disebut perangkat desa. Dibentuk juga Badan Permusyawaratan Desa (BPD), yang merupakan Lembaga perwujudan dan demokrasi dalam penyelenggara pemerintahan desa sebagai unsur penyelenggara pemerintah ditingkat desa. Disamping itu, juga pemerintah memberikan kewenangan kepada desa untuk membentuk mitra pemerintah desa dalam pemberdayaan masyarakat.

Selanjutnya, dalam sistem pemerintahan negara kesatuan republik Indonesia pasal 1 ayat 6, menyatakan bahwa pemerintah desa dan badan permusyawaratan desa, dalam mengatur dan mengurus kepentingan masyarakat setempat yang diakui dan dihormati dalam sistem pemerintahan 
republik Indonesia. Pada pasal 1 ayat 7 menyatakan bahwa pemerintah desa dan perangkat desa sebagai unsur penyelenggara pemerintahan mempunyai peranan dan juga kedudukan yang sangat penting dalam pemerintahan desa. Kepala desa merupakan pemimpin terhadap jalannya urusan pemerintahan yang ada di desa.

Dengan demikian, seorang kepala desa merupakan penyelenggara dan sekaligus sebagai penanggung jawab atas jalannya roda pemerintahan dan pembangunan di dalam wilayahnya, disamping menjalankan urusan pemerintahan dan pembangunan, kepala desa juga mempunyai kewajiban lain yaitu menyelenggarakan program di bidang kemasyarakatan, membina ketenteraman, dan keterlibatan masyarakat serta membina dan mengembangkan jiwa semangat gotong royong masyarakat.

\section{Pemerintahan Desa}

pemerintahan desa, di dalam Peraturan Pemerintah No. 72 Tahun 2005 menyatakan bahwa pemerintah desa atau yang disebut dengan nama lain adalah kepala desa dan perangkat desa sebagai unsur penyelengggaraan pemerintahan desa.

Sebagai unsur penyelenggara pemerintah desa, maka pemerintah desa pada hakikatnya mempunyai tugas dalam menyelenggarakan urusan pemerintahan, pembangunan, dan kemasyarakatan. Oleh karena itu, dilihat dari segi fungsi maka pemerintah desa memiliki fungsi sebagai berikut yaitu:

1. Menyelenggarakan urusan rumah tangga desa;

2. Melaksanakan pembangunan dan pembinaan kemasyarakatan;

3. Melaksanakan pembinaan perekonomian desa;

4. Melaksanakan pembinaan partisipasi dan swadaya gotong royong masyarakat;

5. Melaksanakan pembinaan ketenteraman dan ketertiban masyarakat;

6. Melaksanakan musyawarah penyelesaian perselisihan, dan lain sebagainya.

Selanjutnya, BPD sebagai mitra pemerintah desa dalam menjalankan tugas dan fungsinya, berdasarkan UU No. 32 Tahun 2004 pada pasal 209 disebutkan bahwa BPD berfungsi menetapkan peraturan desa bersama kepala desa, menampung dan menyalurkan aspirasi mawsyarakat. Atas peran dan fungsinya tersebut, dijelaskan dalam PP No. 72 Tahun 2005 bahwa BPD mempunyai wewenang:

1. Membahas rancangan peraturan desa bersama kepala desa;

2. Melaksanakan pengawasan terhadap pelaksanaan peraturan desa dan peraturan kepala desa;

3. Mengusulkan pengangkatan dan pemberhentian kepala desa;

4. Membentuk panitia pemilihan kepala desa;

5. Menggali, menampung, menghimpun, merumuskan dan menyalurkan aspirasi masyarakat; dan

6. Menyusun tata tertib BPB

Dalm hal menjalankan tugasnya, kepala desa mempunyai wewenang yaitu meliputi:

1. Memimpin penyelenggaraan pemerintahan desa berdasarkan kebijakan yang ditetapkan bersama bada permusyawaratan desa;

2. Mengajukan rancangan peraturan desa; 
3. Menetapkan peraturan desa yang telah mendapat persetujuan bersama BPD;

4. Menyusun dan mengajukan rancangan peraturan desa mengenai anggaran pendapatan dan belanja desa untuk dibahas dan ditetapkan bersama BPD;

5. Membina kehidupan masyarakat desa dari tugas dan wewenang kepala desa seperti diatas, maka kepala desa mempunyai peranan dan tanggung jawab yang sangat penting.

\section{Perencanaan Pembangunan}

Perencanaan dapat didefinisikan sebagai suatu kegiatan sosial atau organisasional yang disengaja untuk mengembangkan suatu strategi optimal dari tindakan nyata di masa depan untuk mencapai suatu kumpulan tujuan yang diinginkan untuk memecahkan masalah-masalah dalam konteks yang kompleks dan disertai oleh kekuatan dan keinginan untuk menjalankan sumber daya yang ada dan juga bertindak seperlunya untuk mengimplementasikan strategi terpilih (Arsyad, 2010: 156).

Berdasarkan pengertian diatas, maka pada hakikatnya terdapat enam elemen dasar dari suatu perencanaan yaitu:

1. Merencanakan berarti memilih;

2. Perencanaan merupakan alat pengalokasian sumber daya;

3. Perencanaan merupakan sebuah alat untuk mencapai tujuan;

4. Perencanaan untuk masa depan.

Pandangan pembangunan menurut Saul M. Katz dan Tjokrowinoto (1993: 8), menyatakan bahwa pembangunan adalah pergeseran dari suatu kondisi nasional yang satu menuju ke kondisi lain , yang dipandang lebih baik. Pembangunan itu sendiri dapat diartikan sebagai suatu proses perbaikan yang berkesinambungan atas suatu masyarakat atau suatu sistem sosial secara keseluruhan menuju kehidupan yang lebih baik atau lebih manusiawi (Todaro, 2000: 21).

Pembangunan dapat diartikan oleh masing-masing pakar berbeda antara yang satu dengan yang lainnya, namun pada intinya pembangunan merupakan proses menuju pada perubahan. Beberapa pakar mendifinisikan pembangunan, diantaranya Sondang P. Siagian (2000: 4), yang menyatakan pembangunan sebagai suatu usaha atau rangkaian usaha pertumbuhan dan perubahan yang berencana dan dilakukan secara sadar oleh suatu bangsa, negara, dan pemerintah menuju modernitas dalam rangka pembinaan bangsa.

Hakikat pembangunan adalam membangun masyarakat atau bangsa secara menyeluruh, demi mencapai kesejahteraan rakyat. Untuk bisa membangun lebih baik, masyarakat harus berpendidikan dan bermoral lebih baik. Untuk melakukan pembangunan yang lebih efektif maka masyarakat juga perlu mempelajari sejarah-sejarah bangsa. Mengetahui sejarah adalah penting supaya kita tidak dapat mengulangi kesalahan-kesalahan dari bangsa lain dalam melakukan pembangunan dan memeliharanya. Selain itu, pembangunan harus adil yaitu bagi manusia da adil juga bagi alam, yang kelestariannya harus dipelihara. Disamping itu, keadaan manusia dan alamnya harus lebih baik karena arti pembangunan adalah menjadi lebih baik yang berkelanjutan (Afiffuddin, 2010: 42-49). 
Dalam pembangunan dibutuhkan masyarakat yang mempunyai orientasi saling bergantung, yang oleh Bung Karno disebut masyarakat gotong-royong. Menurut Charlotte Roberts, orientasi tersebut walaupun tidak mengesampingkan kehendak pribadi, memberi pemahaman pribadi yang mendalam kepada seseorang bahwa ia adalah bagian dari masyarakat. Dengan demikian, karena merasa bagian dari masyarakat, maka seseorang tidak berhasrat untuk mendapatkan sesuatu dengan mengorbankan orang lain, bukan karena ia bersimpati atau mengutamakan orang lain, melainkan karena mengakui bahwa nasib bangsa secara keseluruhan tak terelakkan, akan mempengaruhi nasibnya (Afiffuddin, 2010: 48).

Dalam konteksnya yang luas, pembangunan mempunyai beberapa pengertian yang didasarkan pada sudut pandang yang berbeda-beda. Beberapa pengertian pembangunan tersebut ialah:

1. Pembangunan adalah perubahan

Perubahan dalam arti mewujudkan suatu kondisi kehidupan bernegara dan bermasyarakat yang lebih baik dari kondisi sekarang.

2. Pembangunan adalah pertumbuhan

Pertumbuhan maksudnya, kemampuan suatu negara untuk terus selalu berkembang baik secara kuantitatif maupun secara kualitatif sehingga cakupannya adalah seluruh segi kehidupan.

3. Pembangunan adalah rangkaian usaha yang secara sadar dilakukan Keadaan yang lebih baik, yang didambakan oleh suatu masyarakat, serta pertumbuhan yang diharapkan akan terus berlangsung, tidak akan terjadi dengan sendirinya, apalagi secara kebetulan sehingga dibutuhkan suatu rangkaian usaha secara sadar dilakukan.

4. Pembangunan adalah sesuatu rencana yang tersusun secara rapi

Perencanaan mutlak dilakukan oleh dan dalam setiap organisasi, apapun tujuannya, apa pun kegiatannya, tanpa melihat apakah organisasi bersangkutan kecil atau besar. Negara merupakan organisasi sehingga dalam usaha pencapaian tujuan pembangunan para pimpinannya mau atau tidak mau pasti terlibat dalam kegiatan-kegiatan perencanaan.

5. Pembangunan adalah cita-cita akhir dari perjuangan negara atau bangsa Ideologi apapun yang dianut oleh suatu negara bangsa, struktur politik apa pun yang terdapat di masyarakat, sistem perekonomian yang bagaimanapun yang berlaku, dan tata nilai sosial budaya bagaimanapun yang menjiwai kehidupan masyarakat, tetaplah hal-hal yang ingin dicapai atau merupakan cita-cita akhir dari perjuangan suatu negara atau bangsa yaitu meliputi: 1). Keadilan sosial, kemakmuran yang merata, 2). Perlakuan sama dimata hukum, 3). Kesejahteraan material, mental, dan spiritual, 4). Kebahagiaan untuk semua, 5). Ketenteraman dan keamanan.

Sementara itu, perencanaan pembangunan dapat diartikan sebagai suatu usaha sadar, terorganisasi, dan terus-menerus guna memilih alternative yang terbaikdari sejumlah alternative untuk mencapai satu tujuan tertentu (Waterson, 1965). Selain itu, Conyers dasn Hills (1994) menyatakan bahwa perencanaan pembangunan adalah merupakan suatu proses yang berkesinambungan yang mencakup psoses pengambilan keputusan atau memilih berbagai alternative penggunaan sumber daya untuk mencapai tujuan-tujuan tertentu pada masa yang akan datang. 
Dengan demikian, suatu perencanaan sangatlah penting dalam pembangunan karena tanpa adanya perencanaan yang matang maka suatu pembangunan tidak akan berjalan dengan baik atau apa yang menjadi harapan bersama tidak dapat terselenggara sesuai harapan. Oleh karena itu, para pemimpin terlebih khusus dalam hal ini pemerintah desa dituntut untuk dapat merencanakan pembangunan dengan matang yaitu dalam rangka mewujudkan masa depan yang lebih baik daripada sebelumnya.

\section{METODE}

Metode penelitian yang digunakan adalah metode kualitatif. Dalam penelitian ini yang menjadi instrument utama adalah peneliti itu sendiri. Sumber data yang digunakan yata data primer dan data sekunder. Teknik penentuan informan yaitu Teknik purposive sampling. Teknik pengumpulan data yang digunakan yaitu wawancara, observasi, dan dokumentasi. Teknik analisis data dilakukan secara terus menerus sampai tuntas sehingga datanya sudah jenuh.

\section{HASIL DAN PEMBAHASAN}

\section{Pandangan masyarakat terhadap peran pemerintah desa}

Peran masyarakat dapat diukur dengan menggunakan indicator-indikator sebagai berikut:

a. Dalam hal pelayanan masyarakat

Dalam masyarakat tentang peran pemerintah desa menurut informan menunjukkan bahwa kualitas pelayanan, dan pelaksanaan pembangunan di desa tidak berjalan dengan baik. Pendapat ini sejalan dengan hasil penelitian yang dilakukan bahwa ternyata tingkat capaian peran aparatur pemerintah desa dari sisi kualitas pelayanan belum optimal. Artinya, sebagian besar informan yakin bahwa indicator kualitas pelayanan belum tercapai oleh pemerintah desa dalam pelaksanaan pembangunan desa.

b. Dalam hal pemberdayaan masyarakat

Tujuan pemberdayaan masyarakat adalah meningkatkan keberdayaan masyarakat melalui pengetahuan organisasi masyarakat setempat, penanggulangan kemiskinan, dan perlindungan sosial masyarakat, peningkatan keswadayaan masyarakat guna membantu masyarakat, meningkatkan kehidupan ekonomi sosial. Pemberdayaan merupakan suatu kondisi dinamis yang memungkinkan masyarakat mampu membangun dirinya dan lingkungannya berdasarkan potensi, kebutuhan, aspirasi dan kewenangan yang ada pada masyarakat sendiri dengan mengembangkan kemampuan dan kemandirian masyarakat untuk berperan aktif dalam pembangunan agar secara bertahap masyarakat mampu membangun diri dan lingkungan secara mandiri. Hasil penelitian tentang indicator pemberdayaan masyarakat menunjukkan bahwa pelaksanaan kegiatan, pemberdayaan ini tidak berjalan atau tidak pernah ada kegiatan pemberdayaan dalam pelaksanaan pembangunan dan masyarakat.

\section{Peran pemerintah desa}

Variabel peran dapat diukur dengan menggunakan indicator-indikator sebagai berikut: 
a. Efektivitas adalah tingkat pencapaian tujuan

Hasil penelitian menunjukkan bahwa peran pemerintah desa dari indicator efektifitas menyatakan tidak efektif atau sangat rendah peran pemerintah desa dilihat dari indicator ini. Hasil menunjukkan bahwa peran pemerintah desa dalam menunjang pembangunan desa ternyata belum efektig dalam program pembangunan desa. Sebagian besar informan menyatakan bahwa indicator efektivitas belum tercapai atau belum dapat direalisasikan.

b. Responsibilitas

Responsibilitas adalah kemampuan aparat untuk mengenali kebutuhan masyarakat, menyusun agenda dan prioritas pelayanan serta mengembangkan program-program pelayanan publik sesuai dengan kebutuhan dan aspirasi masyarakat penggunaan, yang dapat diamati melalui: a). keterkaitan antara program dan kebutuhan masyarakat; b). ketersediaan kesempatan dan wadah bagi masyarakat untuk menyampaikan saran dan keluhan; c). daya tanggap desa dalam menghadapi dan penyelesaian keluhan-keluhan yang disampaikan oleh masyarakat.

Peran pemerintah desa dilihat dari sikap tanggapan pemerintah desa dalam memberikan sebuah pelayanan atau penyelesaian masalah terhadap masyarakat, ternyata sebagian besar informan menyatakan "tidak tanggap" dalam memberikan suatu pendapat atau menyelesaikan suatu masalah yang ada dimasyarakat. Informan menyatakan bahwa respon pemerintah desa dalam pelaksanaan pembangunan belum bisa dikatakan baik.

c. Keberhasilan pembangunan

Keberhasilan suatu pembangunan yang didefinisikan sebagai keadaan prestasi yang harus dicapai bersama-sama antara pemerintah desa dan masyarakat untuk mewujudkan tingkat ekonomi dan taraf hidup masyarakat, tingkat partisipasi dan kemandirian masyarakat berupa realisasi program-program tentang pembangunan yang sudah diterapkan di desa, yang mana sudah deprogram oleh pemerintah desa. Peningkatan kemampuan berkembang secara mandiri, diukur dari kemampuan memenuhi kebutuhan keluarga secara mandiri, kemampuan dalam mengembangkan usaha, kemampuan dalam menabung, dan sebagainya. Tingkat tercapainya tujuan atau sasaran pembangunan desa harus dapat diperbaiki guna untuk kepentingan bersama dalam kehidupan bermasyarakat. Berdasarkan hasil wawancara maka dapat dijelaskan bahwa kondisi ekonomi dan taraf hidup masyarakat desa belum bisa dikatakan sangat membaik. Hal ini terlihat dari faktor kemandirian masyarakat yang masih rendah dan pencapaian tujuan atau sasaran pembangunan yang belum berjalan optimal.

\section{PENUTUP}

a. Kesimpulan

1. Peran pemerintah desa dalam melaksanakan pembangunan desa, belum dapat dikatakan baik atau belum tercapai dengan optimal tingkat pencapaian keberhasilan pembangunan. Oleh karena itu, untuk dapat meningkatkan pembangunan di desa maka harus adanya faktor-faktor pendukung dengan menggunakan indidkator sebagai berikut: efektivitas adalah tingkat pencapaian tujuan, responsibilitas, dan keberhasilan pembangunan.

2. Macetnya suatu pembangunan desa disebabkan pemerintah desa belum dapat meningkatkan taraf hidup masyarakat. Hal ini dipengaruhi oleh adanya kurangnya 
koordinasi antara pemerintah dengan perangkat desa lainnya, kurangnya ketegasan dalam menjalankan fungsinya sebagai pemerintah desa atau kepala desa.

b. Saran

1. Untuk melaksanakan tugas dan tanggung jawab sebagai pemerintah desa dalam pembangunan, maka dengan demikian akan tercipta suatu hubungan yang baik antara pemerintah desa dengan masyarakat. Dismaping itu, akan membuat masyarakat merasa terpanggil untuk memilih pemimpin-pemimpin mereka secara demokratis.

2. Kepala desa dalam melakukan sosialisasi kepada masyarakat harus dengan jalan menanamkan kesadaran penuh kepada mereka agar mereka memiliki kesadaran untuk berpartisipasi dalam pelaksanaan pembangunan.

\section{Daftar pustaka}

Adisasmita, Rahardjo. 2006. Membangun Desa Partisipatif. Yogyakarta: Graha Ilmu.

Afiffuddin. 2010. Pengantar Administrasi Pembangunan (konsep, teori dan implikasinya di era reformasi). Bandung: ALFABETA.

Arsyad, Lincolin. 2010. Ekonomi Pembangunan. Yogyakarta: UPP STIM YKPN.

Moleong, Lexi. 2006. Metode Penelitian Kualitatif. Bandung: Prenada media group.

Ngusmanto. 2015. Pemikiran \& Praktik Administrasi Pembangunan. Jakarta: Mitra wacana media. 